\title{
Temperature correlated dorso-ventral abdomen flipping of Apis laboriosa and Apis dorsata worker bees
}

\author{
Jerzy WOYKE ${ }^{\mathrm{a} *}$, Jerzy WILDE ${ }^{\mathrm{b}}$, Maria WILDE \\ a Agricultural University - SGGW, Bee Division, 166 Nowoursynowska, 02-787 Warsaw, Poland \\ ${ }^{\mathrm{b}}$ WM University, Apiculture Division, Olsztyn, Poland \\ ${ }^{\mathrm{c}}$ Dabur Apicultural Centre, Jugedi, Chitwan, Nepal
}

(Received 19 September; revised 12 January 2004; accepted 23 January 2004)

\begin{abstract}
Observations were conducted in Nepal, on A. laboriosa nests in the Himalayas, and A. dorsata in Rampur, Chitwan. At low temperatures, A. laboriosa worker bees of the whole nest curtain repeatedly raised the abdomen up and down with its tip at the peak up to $30-40^{\circ}$. Frequency of those movements was correlated with ambient temperature. With the increase in temperature, from $10^{\circ} \mathrm{C}$ to $17^{\circ} \mathrm{C}$, the percentage of workers performing the temperature correlated dorso-ventral abdomen flipping (AF) dropped significantly from $51.4 \%$ to $7.5 \%$. The duration of particular $\mathrm{AF}$ decreased from $0.62 \mathrm{~s}$ at $10^{\circ} \mathrm{C}$ to $0.27 \mathrm{~s}$ at $17^{\circ} \mathrm{C}$. The workers repeated successive AF every $1.75 \mathrm{~s}$ at $10^{\circ} \mathrm{C}$ and every $6.00 \mathrm{~s}$ at $17^{\circ} \mathrm{C}$. A. dorsata performed similar movements. However, the duration of single AF was shorter in A. dorsata than in A. laboriosa, and A. dorsata repeated those movements more frequently than A. laboriosa.
\end{abstract}

Apis laboriosa / Apis dorsata / abdomen flapping / body movements / temperature correlation / Nepal

\section{INTRODUCTION}

Little is known of the biology of Apis laboriosa $\mathrm{F}$. Smith. This bee lives in harsh conditions in the Himalayas. The ambient temperature $\left(\mathrm{t}_{\mathrm{a}}\right)$ drops at night to $5-10^{\circ} \mathrm{C}$. In winter it is low during the whole day $\left(4.5-13.5^{\circ} \mathrm{C}\right)$, and at night $\mathrm{t}_{\mathrm{a}}$ drops below freezing. According to Underwood (1990a, b), A. laboriosa survives the cold winter months of December and January by huddling in energy-efficient comb-less clusters. Little heat is produced and individual bees can chill to temperatures below $4{ }^{\circ} \mathrm{C}$. However, Woyke et al. (2001) showed that in lower warmer Himalayan zones, the bees survive the winter on combs as normal colonies rearing the brood, in comb-right colonies.

It would be interesting to compare the behaviour of A. laboriosa to the closely related species A. dorsata Fabricius. The latter species lives in tropical conditions and often suffers from an excess of heat. However, in northern areas, or high in the mountains, the temperature drops at night to $10{ }^{\circ} \mathrm{C}$ or lower.

We observed dorso-ventral abdomen flipping (AF) performed intensively by A. laboriosa workers at temperatures below $12{ }^{\circ} \mathrm{C}$. Characteristic body movements performed by honey bees were already described. Those concern body movements performed by foragers during the waggle dance (von Frisch, 1923), vibration dance (Fletcher, 1978; Schneider et al., 1986), the defence shimmering performed by A. cerana Fabricius (Butler, 1954; Koeniger and Fuchs, 1975) or the defence movements performed by A. dorsata (Seeley et al., 1982).

We investigated the behaviour of A. laboriosa workers at different ambient temperature $\left(t_{\mathrm{a}}\right)$ to detect any correlation between the

\footnotetext{
* Corresponding author: woyke@alpha.sggw.waw.pl
} 
behaviour and the $\mathrm{t}_{\mathrm{a}}$. Finally, we compared the behavioural reactions of $A$. laboriosa and $A$. dorsata workers.

\section{MATERIALS AND METHODS}

The investigations on A. laboriosa were conducted at two rock-cliff sites in the Himalayas in Nepal in November and December 1999. The first cliff site, which contained 17 nests, was located on the slope of Annapurna mountain in Kyumi near Landrung at the Modi Khola river in Kasaki district (8350' E, $28^{\circ} 22^{\prime} \mathrm{N}$, alt. $1200 \mathrm{~m}$ ). The observations were conducted here during six days, from 27 November to 2 December. Every hour, we observed all 17 colonies. However, more precise estimations on the frequency of abdominal movements were conducted only on 10 nests, which were located parallel to the rock. We repeated those estimates 3 times. Thus, the means that we report represent data for 30 observation periods.

The second cliff site, with 53 nests, was situated in Chale at the Koshi river near the village of Chaku in Sindhupalchok district $\left(85^{\circ} 48^{\prime}\right.$ E, $28^{\circ} 09^{\prime}$ N, alt. $1500 \mathrm{~m}$ ), near the Tibetan border and approximately $200 \mathrm{~km}$ east from the first site. Observations were conducted here on 5 and 6 December.

At the first and second study sites, continuous observations from 08:00 to 16:00 $\mathrm{h}$ were carried out from across the Modi Khola and Koshi rivers, respectively, from a distance of $28 \mathrm{~m}$. The bees were observed with the aid of $12 \times 50$ binoculars. The activities of the workers were recorded with a video camera recorder provided with $24 x$ optical zoom. In addition to the 53 nests monitored at Chale, one other colony in the nearby Chaku village was observed to which direct access was possible. Activities of bees were recorded here from a distance of $0.5-2 \mathrm{~m}$. The intention was to evaluate the percentage of workers making abdominal dorso-ventral movements at different temperatures. The temperature correlated abdominal dorso-ventral movements (AF) performed by worker bees of the curtain were recorded during $3 \mathrm{~min}$, each hour, from 09:00 to 16:00 h. On the video screen, 5 rows of worker with 12 bees in each row (altogether 60) were visible. The number of workers performing the movements was counted during $3 \mathrm{~s}$. The ratio of this number, to the total number of bees visible on the screen, gave the percentage of bees performing the behaviour. The counts were repeated 10 times within the $3 \mathrm{~min}$ record. Together, 80 counts ( $8 \mathrm{~h}, 10$ repetitions) of workers performing $\mathrm{AF}$ were made during the day.

We measured two aspects of the duration of $\mathrm{AF}$ behaviour. First, we estimated the duration of the AF movement itself. The duration of particular $\mathrm{AF}$ was measured after the video was displayed in very slow mode (frame after frame). The number of frame in which the phenomenon occurred was counted and next it was multiplied by 0.04 (frame succession speed $1 \mathrm{~s}: 25=0.04$ ).

Second, we measured the duration of an $\mathrm{AF}$ cycle, defined as the time elapsing from the beginning of one movement, through the duration of that movement plus the duration of the rest interval up to the beginning of the next movement. To determine the duration of $\mathrm{AF}$ cycles, the duration from the beginning of one movement to the beginning of one of the several successive movements (3-7) was measured with a stopwatch. Next, that total duration was divided by the number of intervals (2-6) between those movements.

Air temperature and relative humidity were recorded every hour with an electronic thermo hygrometer (Model No Ethg-912, Oregon Scientific) placed in the shade, $1 \mathrm{~m}$ above the ground.

During the six months from October to April, fourteen consecutive full day observations were conducted on 7 and $19 \mathrm{~A}$. dorsata nests at two buildings at the Tribhuvan University campus in Rampur, in southern Nepal, in the Chitwan district (84 $21^{\circ}$ E, $27^{\circ} 39^{\prime} \mathrm{N}$, alt. about $200 \mathrm{~m}$ ). The nests were observed from a distance of $4-5 \mathrm{~m}$. Three nests were observed through windows from a distance of $0.5 \mathrm{~m}$.

ANOVA was applied and LSD was used to determine significant differences between the means. All percentages were transformed for statistical calculations according to the arcsine formula. Correlation coefficients were calculated between the percentage of workers performing $\mathrm{AF}$ and both the ambient temperature and $\mathrm{RH} \%$.

A video recording the dorso-ventral abdomen movements of A. laboriosa and A. dorsata worker bees is presented in the version on line.

\section{RESULTS}

\subsection{Dorso-ventral abdomen flipping of $A$. laboriosa}

The close up observation and video recording conducted in Chaku revealed that A. laboriosa workers performed dorso-ventral abdomen flipping (AF). The workers lifted the abdomen up and down between spread wings. The thorax was not moved. No wing movements were made. The abdomen was lifted up to $30^{\circ}-40^{\circ}$, with a mean of $36^{\circ} \pm 3.4^{\circ}( \pm S D, n=30)$, in relation to normal position. The movements did not have the character of the side-to-side shaking called "shimmering". Worker bees made such 
Table I. Temperature correlated dorso-ventral abdomen flipping (AF) of Apis laboriosa workers at Annapurna slope, Kyumi, 1999. Presence or absence of AF (+ or -) or percentage of curtain workers performing such movements (\% AF).

\begin{tabular}{|c|c|c|c|c|c|c|c|c|c|}
\hline \multirow{2}{*}{$\begin{array}{l}\text { Local } \\
\text { Time }\end{array}$} & \multicolumn{3}{|c|}{30 Nov. } & \multicolumn{3}{|c|}{$1 \mathrm{Dec}}$. & \multicolumn{3}{|c|}{2 Dec. } \\
\hline & Temp & $\mathrm{RH}$ & $\mathrm{AF}$ & Temp & RH & $\mathrm{AF}$ & Temp & $\mathrm{RH}$ & $\mathrm{AF}$ \\
\hline $\mathrm{h}$ & ${ }^{\circ} \mathrm{C}$ & $\%$ & + or - & ${ }^{\circ} \mathrm{C}$ & $\%$ & $\%$ & ${ }^{\circ} \mathrm{C}$ & $\%$ & $\%$ \\
\hline 9 & 9 & 95 & + & 9 & 91 & 50 & 9 & 97 & 50 \\
\hline 10 & 10 & 98 & + & 11 & 91 & 30 & 11 & 96 & 30 \\
\hline 11 & 12 & 97 & + & 16 & 72 & 10 & 16 & 78 & 10 \\
\hline 12 & 18 & 71 & + & 21 & 65 & 0 & 21 & 59 & 5 \\
\hline 13 & 19 & 71 & - & 23 & 47 & 0 & 23 & 43 & 0 \\
\hline 14 & 20 & 71 & - & 24 & 44 & 0 & 20 & 52 & 0 \\
\hline 15 & 22 & 57 & - & 22 & 46 & 0 & 17 & 70 & 10 \\
\hline 16 & 17 & 66 & + & 19 & 65 & 3 & 15 & 78 & 15 \\
\hline \multirow{3}{*}{\multicolumn{4}{|c|}{$\begin{array}{l}\text { Correlation between \% AF } \\
\text { and }{ }^{\circ} \mathrm{C} \text { or } \mathrm{RH} \%\end{array}$}} & $\mathrm{r}=-0.99$ & 0.97 & & -0.96 & 0.91 & \\
\hline & & & & $P<0.001$ & 0.001 & & 0.001 & 0.001 & \\
\hline & & & & $\mathrm{n}=9$ & 9 & & 9 & 9 & \\
\hline
\end{tabular}

Each \% of AF presents rough mean of 30 records (10 colonies, 3 repetitions).

movements all over the curtain nest. We did not notice visible differences in the percentage of workers making $\mathrm{AF}$ in different parts of the nest.

\subsection{Percentage of Apis laboriosa workers performing abdomen flipping at different ambient temperatures}

During the six whole day observations at the Annapurna slope, many workers at the curtain performed AF. On Nov. 301999 when the presence or absence of those movements was noticed, considerable variations in the frequency of AF during the day were observed (Tab. I). The workers made AF in the morning when the temperature was low. They did not make such movements in the afternoon when the temperature rose, and made them again late in the afternoon and in the evening when the temperature had dropped again. We remarked that more workers made AF when the temperature was lower. Therefore, the proportion of workers participating in those movements was recorded on subsequent days. Workers of all colonies performed AF. More accurate estimates conducted on the 10 nests located parallel to the rock are presented in Table I.

From the other side of the river, we were able to estimate whether every second worker
(50\%), every third $(\approx 30)$, and so on, performed AF. However, we were not able to detect whether this was $55 \%$ or $45 \%$ and so on. We did not notice visible differences in the percentage of AF performed by workers of the 10 nests during the 3 repetitions conducted on the hour. Therefore, only one number of the percentage of AF is presented in Table I, for each hour, without ranges and variations. The number presents one rough mean of 30 estimates (10 nests, 3 repetitions). We noticed that every second worker (50\%) flipped the abdomen on Dec. 1 and 2 at 08:00 and 09:00 h, when the ambient temperature $\left(\mathrm{t}_{\mathrm{a}}\right)$ was $7-9{ }^{\circ} \mathrm{C}$. With the increase of $\mathrm{t}_{\mathrm{a}}$, the $\%$ of AF decreased. Above $21^{\circ} \mathrm{C}$ no $\mathrm{AF}$ were noticed. In the evening, when the $\mathrm{t}_{\mathrm{a}}$ dropped to $17-19{ }^{\circ} \mathrm{C}$, again $\mathrm{AF}$ were performed.

In Chale, on December 5 and 6, we observed that workers of all 53 colonies performed AF. The movements were made by workers of comb-right colonies, as well as the six combless clusters. More workers performed such movements at lower temperatures up to $15^{\circ} \mathrm{C}$, and less above that temperature. However, detailed records were not taken.

Instead, the easy access to the nest in Chaku enabled us a close-up video recording on December 6, 1999. Data presented in Figure 1 concern video records conducted at the upper 


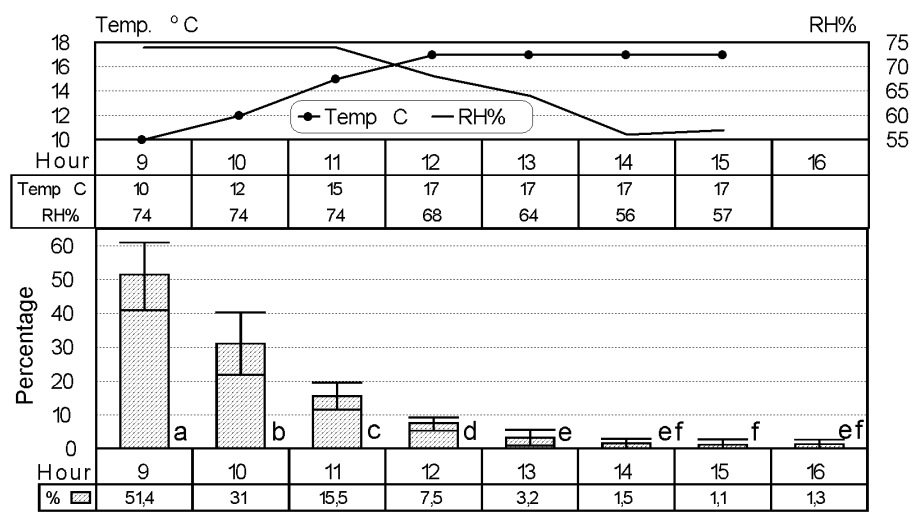

Apis laboriosa

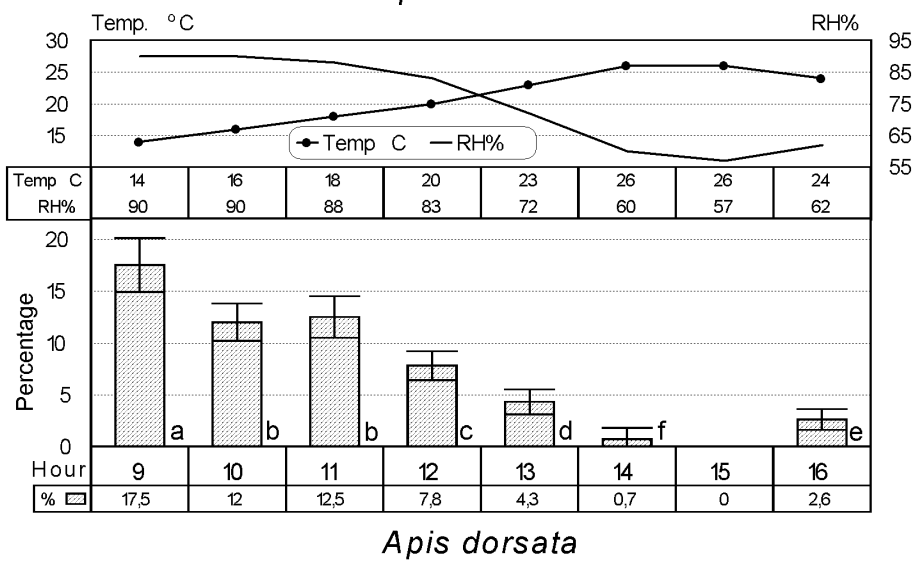

Figure 1. Percentage of A. laboriosa and A. dorsata worker bees performing abdomen flipping at different day time in relation to ambient temperature and relative humidity. Different letter near bars indicate significant differences between means, error bars present SD.

centre of the nest, $10 \mathrm{~cm}$ above the curtain mouth. With the increase in $\mathrm{t}_{\mathrm{a}}$, from $10^{\circ} \mathrm{C}$ to $17{ }^{\circ} \mathrm{C}$, the $51.4 \%$ of $\mathrm{AF}$ decreased significantly to $1 / 7$ of the value. Thus, the results collected at Annapurna and in Chaku were similar.

The decrease of the \% of AF was highly negatively correlated with the increase of $t_{a}$ in both places (Tabs. I and II).

\subsection{Pattern, duration and repetition of abdomen flipping at different ambient temperature}

In the morning, at 09:00 $\mathrm{h}$ and temperature $10{ }^{\circ} \mathrm{C}$, the workers made 2 or 3 successive AF one immediately after the next. Then, single AF were performed with a short interval pause
$(1.1 \mathrm{~s})$ between them. The pattern of successive AF was like this: $2,2,1,1,1 \ldots ; 2,3,1,1,1 \ldots$; $3,1,1,1 \ldots$ At 10:00 $\mathrm{h}$ and later, at a temperature of $12{ }^{\circ} \mathrm{C}$ and higher, only repeated single AF were observed.

The duration of particular AF was $0.62 \mathrm{~s}$ at 09:00 $\mathrm{h}$ and temperature $10^{\circ} \mathrm{C}$ (Fig. 2). As the time passed and the temperature increased to $17^{\circ} \mathrm{C}$, the duration decreased significantly by more than half of the time. The duration of $\mathrm{AF}$ was negatively correlated with $\mathrm{t}_{\mathrm{a}}$ and positively with the \% of AF (Tab. III).

The repetition time between the beginning of one single AF (through its duration and the duration of the rest period) to the beginning of the next one was $1.75 \mathrm{~s}$ at 09:00 $\mathrm{h}$ and temperature $10{ }^{\circ} \mathrm{C}$. (Fig. 2). As the time passed and the 
Table II. Correlation between percentage of workers performing abdominal flipping and ambient air temperature or $\mathrm{RH} \%$.

\begin{tabular}{|c|c|c|c|}
\hline \multicolumn{4}{|c|}{ A. laboriosa, Chaku, 6 December 1999} \\
\hline air temp & ${ }^{\circ} \mathrm{C}$ & $\mathrm{r}=-0.92, P<0.001, \mathrm{n}=70$ & $\mathrm{R}$-squared $=85 \%$ \\
\hline humidity & $\mathrm{RH} \%$ & $\mathrm{r}=0.74, \quad P<0.001, \mathrm{n}=70$ & R-squared $=55 \%$ \\
\hline \multicolumn{4}{|c|}{ A. dorsata, Rampur 20 December 1999} \\
\hline air temp & ${ }^{\circ} \mathrm{C}$ & $\mathrm{r}=-0.94, P<0.01, \mathrm{n}=70$ & R-squared $=88 \%$ \\
\hline humidity & $\mathrm{RH} \%$ & $\mathrm{r}=0.92, P<0.01, \mathrm{n}=70$ & R-squared $=84 \%$ \\
\hline
\end{tabular}

Table III. Correlation between duration (s) of single abdomen flipping (AF), or repetition time between two successive AF and ambient air temperature or percentage of workers performing AF.

\begin{tabular}{|c|c|c|c|}
\hline Correlation between & Duration of AF & or & Repetition of AF after s \\
\hline \multicolumn{4}{|c|}{ A. laboriosa } \\
\hline and temp. ${ }^{\circ} \mathrm{C}$ & $\mathrm{r}=-0.91 P<0.001 \mathrm{n}=40$ & & $\mathrm{r}=0.67, \quad P<0.001, \mathrm{n}=40$ \\
\hline and $\%$ of $\mathrm{AF}$ & $\mathrm{r}=0.92 P<0.001 \mathrm{n}=40$ & & $\mathrm{r}=-0.65, P<0.001, \mathrm{n}=40$ \\
\hline \multicolumn{4}{|c|}{ A. dorsata } \\
\hline and temp. ${ }^{\circ} \mathrm{C}$ & $\mathrm{r}=-0.58 P<0.001 \mathrm{n}=50$ & & $\mathrm{r}=0.54, \quad P<0.002, \mathrm{n}=30$ \\
\hline and $\%$ of $\mathrm{AF} \%$ & $\mathrm{r}=0.51 P<0.001 \mathrm{n}=50$ & & $\mathrm{r}=-0.20, P<0.293, \mathrm{n}=30$ \\
\hline
\end{tabular}

temperature rose to $17^{\circ} \mathrm{C}$, the bees repeated $\mathrm{AF}$ 3.4 times less frequently. Later on that day, the AFs were very rare. Single repetitions of AF after 7 or $13 \mathrm{~s}$ were noticed. The increase of the time after which AF were repeated was positively correlated with the increase of $t_{a}$, and negatively with the $\%$ of AF (Tab. III).

\subsection{Abdomen flipping of Apis laboriosa workers at different ambient relative humidity}

When the $t_{a}$ raised, the relative air humidity (RH) dropped (Fig. 1). The percentage of AF decreased significantly when the RH dropped. The decrease of the percentage of AF was significantly correlated with the decrease of RH (Tab. II). However, the correlation coefficient between the percentage of AF and $t_{a}$ was higher then between percentage of $\mathrm{AF}$ and the $\mathrm{RH}$. The R-Squared statistics for $t_{a}$ explained the variability in higher percentage than for $\mathrm{RH}$ (Tab. II). Thus, there was a closer relationship between the $\%$ of AF and the $t_{a}$, than between that and the RH\%. It is worthy of note that the $\mathrm{t}_{\mathrm{a}}$ in Chaku 6 Dec. was $17^{\circ} \mathrm{C}$ at $12: 00 \mathrm{~h}$ and it did not change till 15:00 h. However the RH\% dropped during that time from $68 \%$ to $57 \%$, and the percentage of AF decreased from $7.5 \%$ to $1.1 \%$. It is likely, that factors other than $\mathrm{t}_{\mathrm{a}}$ have also some influence on the percentage of AF.

\subsection{Abdomen flipping of Apis laboriosa workers at different altitude of the sun on the sky}

The sun rose and set December 1 in Pokhara city near the Kyumi site on Annapurna slop at 0658 and $1728 \mathrm{~h}$ respectively. It rose and set December 6 in Kathmandu at 06:56 and $17: 24 \mathrm{~h}$ respectively. Since Chaku is about 30 " east, the sun rose and set there about $2 \mathrm{~min}$ earlier. The percentage of AF decreased from $50 \%$ or $51.4 \%$ to $0.0 \%$ or $7.5 \%$, within the period 2:00 $\mathrm{h}$ to 5:00 $\mathrm{h}$ after sunrise (Tab. IV). However, the $\%$ of AF increased from $0.0 \%$ or $5.4 \%$ to only $1.2 \%$ or $12.5 \%$, within the period 5:00 $\mathrm{h}$ to 2:00 $\mathrm{h}$ before the sun set. Without statistical calculations it is obvious that the frequency distribution of the percentage of $\mathrm{AF}$ within the period 2:00 $\mathrm{h}$ to 5:00 $\mathrm{h}$ after sunrise differs significantly from that 2:00 $\mathrm{h}$ to $5: 00 \mathrm{~h}$ before sunset. Thus, the percentage of AF was not related to the altitude of the sun on the sky. 

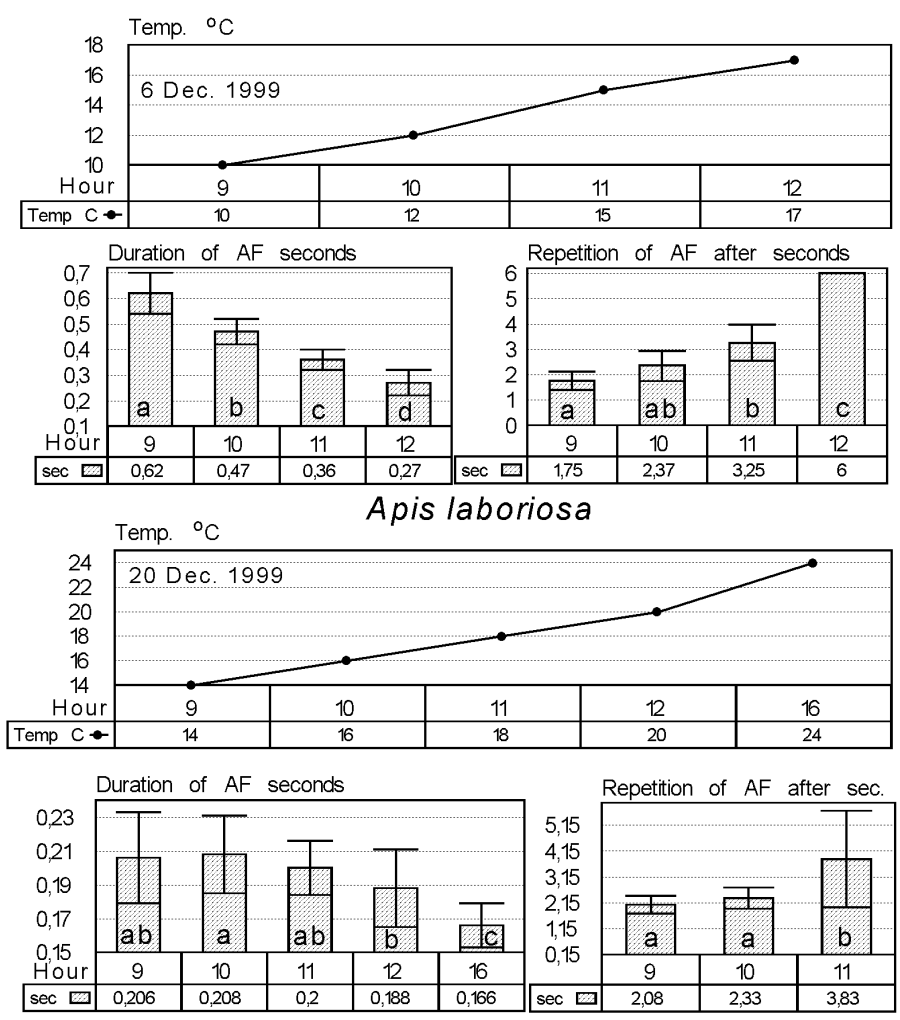

Apis dorsata

Figure 2. Duration of single abdomen flipping and repetition time between successive flipping performed by A. laboriosa and A. dorsata workers at different day time in relation to ambient temperature. Explanation see Figure 1.

\subsection{Abdomen flipping of Apis laboriosa workers during different activities}

A. laboriosa workers start foraging at $10{ }^{\circ} \mathrm{C}$ and the number of workers leaving the nest double at $12{ }^{\circ} \mathrm{C}$ (Woyke et al., 2003b). We observed that during this activity the curtain mouth is created. The workers are here not hanging vertically but are in disorder. The foragers leave and return to this area. The recruiting dances are also performed here. We did not see any AF within the mouth area. Even at the lowest ambient temperature, at which the foraging activity just started, and the percentage of AF was the highest, no AF were performed within the mouth. However, just outside it, as well as at the rest of the curtain, AF was performed.
A. laboriosa workers perform periodic mass flight during the day (Woyke et al., 2003a). They start those flights at $12{ }^{\circ} \mathrm{C}$, when the workers perform AF. We observed that shortly before those flights started, as well as during that activity, the total curtain was in disorder. We did not observe any AF performed during that flight activity at any part of the curtain.

In December in Chale, there were combright colonies as well as comb-less clusters. Worker bees at the curtains of both types of bee aggregations performed $\mathrm{AF}$ at appropriate ambient temperatures.

When an intruder approached the nest, or a hornet was hunting nearby, characteristic defensive circular waves occurred at the curtain. As soon as the waves passed the curtain, AFs were performed at the appropriate temperature. 
Table IV. Percentage of A. laboriosa worker bees performing abdomen flipping (AF\%) and the time (h) after sunrise (+) or before sunset (-).

\begin{tabular}{lcccc}
\hline $\begin{array}{l}\text { Local } \\
\text { time } \\
\mathrm{h}\end{array}$ & $\begin{array}{c}\text { Time } \mathrm{h} \\
\text { after sunrise }+ \\
\text { or before sunset }-\end{array}$ & $\begin{array}{c}\text { Dec. } \\
\text { AF }\end{array}$ & $\begin{array}{c}2 \text { Dec. } \\
\text { AF } \\
\%\end{array}$ & $\begin{array}{c}\text { Dec. } \\
\text { AF } \\
\%\end{array}$ \\
\hline & & After sunrise & & - \\
$08: 00$ & +1 & 50.0 & 50.0 & 51.4 \\
$09: 00$ & +2 & 50.0 & 50.0 & 31.0 \\
$10: 00$ & +3 & 30.0 & 30.0 & 15.5 \\
$11: 00$ & +4 & 10.0 & 10.0 & 7.5 \\
$12: 00$ & +5 & 0.0 & 5.0 & 5.4 \\
$12: 30$ & -5 & Before sunset & & 2.4 \\
$13: 30$ & -4 & 0.0 & 2.5 & 1.3 \\
$14: 30$ & -3 & 0.0 & 0.0 & 1.2 \\
$15: 30$ & -2 & 0.0 & 5.0 & $>1.3$ \\
$16: 30$ & -1 & 1.5 & 12.5 & $>15.0$ \\
\hline
\end{tabular}

\subsection{Temperature correlated dorso-ventral abdomen flipping performed by Apis dorsata}

During our observations in Rampur, the $t_{a}$ in February dropped at night as low as $6{ }^{\circ} \mathrm{C}$. In the morning it raised up to $10-12{ }^{\circ} \mathrm{C}$. In this conditions A. dorsata workers of some colonies were found to abandon the lower parts of combs and to cluster in the form of a ball in the upper parts. At $\mathrm{t}_{\mathrm{a}}$ below $12{ }^{\circ} \mathrm{C} \mathrm{A}$. dorsata workers of the outside layers of both, normal curtains and those clustered as balls were chilled and no any AF was observed.

However in December, at higher $\mathrm{t}_{\mathrm{a}}, A$. dorsata workers performed AF. At $\mathrm{t}_{\mathrm{a}} 14{ }^{\circ} \mathrm{C}, 17.5 \%$ of workers flipped the abdomen (Fig. 1). At higher temperatures significantly less workers performed such movements. At $26^{\circ} \mathrm{C}$, very few or non $\mathrm{AF}$ was made. The percentage of workers performing AF significantly decreased when the temperature increased $(\mathrm{r}=-0.94)$, and the $\mathrm{RH}$ decreased.

The mean duration of single AF at $14{ }^{\circ} \mathrm{C}$ was $0.206 \mathrm{~s}$ (Fig. 2). The duration was significantly shorter at higher $\mathrm{t}_{\mathrm{a}}$. The decrease of the duration was correlated with the increase of $t_{a}$ and decrease of the $\%$ of AF (Tab. III).

The same worker bee repeated $\mathrm{AF}$ at $14{ }^{\circ} \mathrm{C}$ after $2.08 \mathrm{~s}$ (Fig. 2). At higher $\mathrm{t}_{\mathrm{a}}$ the repetition was significantly delayed. The delay was significantly correlated with the increase of $t_{a}$ (Tab. III).
The percentage of $\mathrm{AF}$ at $\mathrm{t}_{\mathrm{a}} 14-17^{\circ} \mathrm{C}$ were similar in A. laboriosa and A. dorsata (Fig. 1). However, at similar $\mathrm{t}_{\mathrm{a}}$ the duration of single AF as well as the repetition time, both were in $A$. laboriosa about 1.5 times longer than in A. dorsata (Fig. 2).

\section{DISCUSSION}

We found that both, A. laboriosa and A. dorsata workers of the nest curtain perform temperature-correlated AF. The AFs were more intensive at lower temperatures. However, it happened, 6 Dec. that the percentage of $\mathrm{AF}$ gradually decreased as the time passed, despite the $\mathrm{t}_{\mathrm{a}}$ of $17^{\circ} \mathrm{C}$ did not change (Fig. 1). It has been shown above that within that time RH decreased. This may suggest, that the $t_{a}$ rose although it was not recorded $1 \mathrm{~m}$ above the ground. Possibly other factors, like RH may also modify the reaction to ambient temperature.

Nonetheless, it seems that another phenomenon besides ambient temperature may better explain the daily patterns of AF activity observed during the afternoon. According to Underwood (1990a), the temperature of $A$. laboriosa cluster may remain below the temperature of the surrounding air for several hours during the day. Certainly, workers of the most outside curtain layer performing the AF feel the temperature around them. This temperature is the result of the interaction of both, the $t_{\mathrm{a}}$ as well 
as the temperature of the nearest workers beneath. When the $t_{a}$ raises, than the temperature around the workers performing $\mathrm{AF}$ also rises. However, when $t_{a}$ is higher than the temperature of the several external layers of curtain bees and does not change, then the heat is absorbed by those layers of bees, and their body temperature increases. Consequently, the temperature in the vicinity of workers performing AF also increases. As a result, the workers react as in higher temperature although the $\mathrm{t}_{\mathrm{a}}$ did not change. Similarly $A$. dorsata starts foraging at higher $\mathrm{t}_{\mathrm{a}}$ when the morning temperature was lower. The curtain workers required time to be heated (Woyke et al., 2003b).

According to Underwood (1990a, b) A. laboriosa workers survive the cold winter months in energy-efficient comb-less clusters and an individual bee can be chilled. However, Woyke et al. (2001) showed that at lower altitudes the bees survive the winter in comb-right colonies. In our investigations, $6{ }^{\circ} \mathrm{C}$ was the lowest temperature we recorded (December 6 1999 at 07:30 h). Under such conditions, worker bees in both comb-right nests, as well as combless clusters, performed AF. Perhaps at temperatures, below freezing, and lack of stores, the bees at the outside curtain layer can chill, as Underwood (1990a, b) reported, and thus no AF would be performed. Similarly, we showed that $A$. dorsata workers of the outside layers of bee curtain chilled at $\mathrm{t}_{\mathrm{a}}$ below $12{ }^{\circ} \mathrm{C}$, and $\mathrm{AF}$ was not performed at those temperatures.

It is known, that heat inside a bee colony is produced by contraction of thorax muscles of worker bees. In low $t_{a}$, the temperature of the mantle of a cluster is lower than the temperature of the core (reviewed by Seeley, 1985). According to Burgett and Titayavan (1993) the brood temperature of $A$. dorsata varied between 28 and $39^{\circ} \mathrm{C}$ (mean $\left.33^{\circ} \mathrm{C}\right)$. The change of temperature outside the bee nest presents a cue indicating the need for heating or cooling the nest. According to Heran (1952) A. mellifera workers are able to determine $0.25^{\circ} \mathrm{C}$ change in $t_{a}$. We showed, that the changes of $t_{a}$ presented a cue for the intensity of AF. It is generally known that muscle contractions repeated for a long time produce some heat. Therefore, we speculate that many contractions of muscles raising the abdomen may produce some heat. This would raise the temperature of the outside worker layer of the nest curtain.
Roepke (1930) noticed that $A$. dorsata curtain workers sometimes made fluctuating abdominal movements. He did not explain this behaviour. He did not present the temperature at which such movements were made, and he did not link those movements with the ambient temperature. Those movements could be the ones observed by us AF of A. dorsata. We showed that $\mathrm{AF}$ at higher $\mathrm{t}_{\mathrm{a}}$ are performed rarely or not at all. This explains why AF is rarely observed in A. dorsata, which occupies mostly tropical and subtropical areas.

One may consider the AF of A. laboriosa and $A$. dorsata as signals conveying some information. Characteristic body movements conveying some information were described in A. mellifera $\mathrm{L}$. During the waggle and tremble dance (von Frisch, 1923; Seeley, 1992) or defence shimmering (Butler, 1954; Koeniger and Fuchs, 1975) the workers shake their bodies, from side to side. The workers inform the nest mates about food sources, need to rise nectar processing or presence of enemies. During the vibration dance, dorso-ventral abdominal movements lasting about $2 \mathrm{~s}$ are performed (Hamman, 1957). The abdomen is lowered by about $35^{\circ}$ in relation to normal position (measured by J. Woyke in figure presented by Hamman). Five or six shaking movements are made (Milum, 1955). It is supposed that this signal increases activity in both the queen as well as workers (Hamman, 1957; Fletcher, 1978; Schneider et al., 1986). A. dorsata and A. laboriosa turn their whole body dorso-ventrally while performing their defence movements (personal observations). No correlation was examined between daily ambient temperature changes and intensity of those, above mentioned characteristic body movements. The behaviour described by us, dorso-ventral AF performed by A. laboriosa and A. dorsata, differs from movements presented above. The AF is correlated with daily $t_{a}$ changes and is performed mostly in temperatures below $17^{\circ} \mathrm{C}$ or $25^{\circ} \mathrm{C}$ respectively. It is continued for several hours, and the abdomen is lifted up to $40^{\circ}$ in relation to normal position. We suggest that workers performing AF may convey information about the temperature on the surface of the curtain. This could inform the workers inside the nest of the requirement of heat production. Further investigations are required to prove this suggestion. 


\section{ACKNOWLEDGEMENTS}

We would like to thank very much the chairman of the Dabur Company A.C. Burman for providing us the facilities to conduct these investigations in Nepal. We thank also R. Kolasinski M. Sc., for his initiative to conduct research investigations in Nepal, and for his interest and help.

Résumé - Le battement dorso-ventral de l'abdomen des ouvrières d'Apis laboriosa et d'Apis dorsata est corrélé avec la température. On connaît peu la biologie d'Apis laboriosa F. Smith. Nous avons fait des observations au Népal sur le battement dorso-ventral particulier de l'abdomen (AF) d'ouvrières d'A. laboriosa et d'Apis dorsata Fabricius. Deux sites en falaise comportant 17 et 53 nids d'A. laboriosa ont été observés en novembre et décembre 1999 dans l'Himalaya, depuis l'autre rive de la rivière à l'aide de jumelles $12 \times 50$. Une colonie a été observée à la distance de 0,5 à $2 \mathrm{~m}$. Nous avons aussi observé 7 et 19 nids d'A. dorsata sur deux bâtiments du campus universitaire de Trubhuvan à Rampur, Chitwan (sud du Népal). La prise de vue vidéo en ligne a montré que les ouvrières d'A. laboriosa et d'A. dorsata exécutent l'AF. Nous avons observé des mouvements à basse température. Les AFétaient corrélés avec la température ambiante. Les ouvrières d'A. laboriosa ont de façon répétée soulevé leur abdomen et le plus souvent en faisant un angle de $30^{\circ}-40^{\circ}$. Lorsque la température passait de $10^{\circ} \mathrm{C}$ à $17{ }^{\circ} \mathrm{C}$, le pourcentage d'ouvrières qui exécutaient l'AF a chuté significativement de 51,4\% à 7,5\%. A $21{ }^{\circ} \mathrm{C}$ aucune ouvrière ou seulement $5 \%$ faisaient ces mouvements. De $22^{\circ} \mathrm{C}$ à $24^{\circ} \mathrm{C}$ aucun $\mathrm{AF}$ n'a été observé. Le soir, quand la température tombait à $15{ }^{\circ} \mathrm{C}$, de nouveau $15 \%$ des ouvrières exécutaient l'AF. Le coefficient de corrélation entre la température ambiante et le pourcentage d'ouvrières exécutant l'AF était de $r=-0,92$. La durée de l'AF est passée de $0,62 \mathrm{~s}$ à $10^{\circ} \mathrm{C}$ à $0,27 \mathrm{~s}$ à $17^{\circ} \mathrm{C}$. Les ouvrières répétaient l' $\mathrm{AF}$ toutes les $1,75 \mathrm{~s}$ à $10^{\circ} \mathrm{C}$ et toutes les $6,00 \mathrm{~s}$ à $17^{\circ} \mathrm{C}$. A. dorsata a exécuté un battement dorso-ventral de l'abdomen semblable à celui d'A. laboriosa. Néanmoins l'AF durait moins longtemps et était moins souvent répété que chez d'A. laboriosa. Nous émettons l'hypothèse que de nombreuses contractions musculaires soulevant l'abdomen et répétées longtemps peuvent produire de la chaleur. Nous suggérons aussi que les ouvrières qui exécutent l' $\mathrm{AF}$ pourraient transmettre aux ouvrières à l'intérieur du nid, l'information concernant la température à la surface du rideau d'abeilles et le besoin de produire de la chaleur.

Apis laboriosa / Apis dorsata / frappement de l'abdomen / mouvement corporel / corrélation avec la température / Népal
Zusammenfassung - Temperatur im Zusammenhang mit dorso-ventralem Schlagen des Abdomens der Arbeiterinnen bei Apis laboriosa und Apis dorsata. Über die Biologie von Apis laboriosa F. Smith ist noch wenig bekannt. In Nepal beobachteten wir ein eigenartiges dorso-ventrales ruckartiges Schlagen des Abdomen (AF) bei A. laboriosa und A. dorsata Fabricius. Zwei Felswände mit 17 und 53 A. laboriosa Nestern wurden beobachtet im Himalaya im November und Dezember 1999. Die Nester wurden von der anderen Seite des Flusses mit Hilfe eines $12 \times 50$ Fernglases beobachtet. Ein Volk wurde aus einer Entfernung von 0,5 bis $2 \mathrm{~m}$ beobachtet. Wir beobachteten auch 7 und 19 Apis dorsata Nester an zwei Gebäuden im Campus der Tribhuvan Universität in Rampur, Chitwan in Süd-Nepal. Das Video im Internet zeigt AF bei A. laboriosa und $A$. dorsata Arbeiterinnen. Wir beobachteten diese Bewegungen bei niedrigen Temperaturen. Die AFs waren korreliert mit der Umgebungsemperatur. $A$. laboriosa Arbeiterinnen hoben wiederholt die Spitze ihres Abdomens am häufigsten um 30-40 Winkel. Mit der Zunahme der Temperatur von $10{ }^{\circ} \mathrm{C}$ auf $17{ }^{\circ} \mathrm{C}$, nahm der Prozentsatz von Arbeiterinnen mit AF signifikant von $51,4 \%$ auf $7,5 \%$ ab. Bei $21^{\circ} \mathrm{C}$ machte entweder keine oder nur $5 \%$ der Arbeiterinnen diese Bewegungen. Bei $22^{\circ} \mathrm{C}-24{ }^{\circ} \mathrm{C}$ wurde kein AF bemerkt. Am Abend, wenn die Temperatur auf $15{ }^{\circ} \mathrm{C}$ fiel, begannen wieder $15 \%$ der Arbeiterinnen auf dem Vorhang mit dem AF. Der Korrelationskoeffizient zwischen Umgebungstemperatur und dem Prozentsatz der Abdomen schlagenden Arbeiterinnen betrug $r=-0,92$. Die Dauer des AF sank von $0,62 \mathrm{~s}$ bei $10^{\circ} \mathrm{C}$ auf $0,27 \mathrm{~s}$ bei $17^{\circ} \mathrm{C}$. Die Arbeiterinnen wiederholten AF alle $1,75 \mathrm{~s}$ bei $10^{\circ} \mathrm{C}$ und alle $6,00 \mathrm{~s}$ bei $17^{\circ} \mathrm{C}$. A . dorsata führte ähnliche $\mathrm{AF}$ durch. Die Dauer eines einzelnen $\mathrm{AF}$ war jedoch bei $A$. dorsata kürzer als bei A. laboriosa, und A. dorsata wiederholte diese Bewegungen häufiger A. laboriosa.

Wir vermuten, dass viele Muskelkontraktionen beim lange Zeit wiederholten Heben des Abdomens etwas Wärme erzeugt. Wir schlagen auch vor, dass Arbeiterinnen, die AF durchführen, Informationen über die Außentemperatur am Vorhang und die benötigte Wärmeproduktion weitergeben an die Arbeiterinnen unterhalb des Vorhangs.

Apis laboriosa / Apis dorsata / Abdomenschlagen / Körperbewegung / Temperaturkorrelation / Nepal

\section{MATERIAL ON LINE}

1. At $10{ }^{\circ} \mathrm{C}$, about $50 \%$ of A. laboriosa worker bees perform abdomen flipping http://www.edpsciences.org/apido/

2. At $15{ }^{\circ} \mathrm{C}$, about $15 \%$ of A. laboriosa worker bees perform abdomen flipping http://www.edpsciences.org/apido/ 
3. At $19{ }^{\circ} \mathrm{C}$ about $12.5 \%$ of $A$. dorsata workers perform abdomen flipping

http://www.edpsciences.org/apido/

4. At $24^{\circ} \mathrm{C}$ about $2.5 \%$ of $A$. dorsata workers perform abdomen flipping

http://www.edpsciences.org/apido/

\section{REFERENCES}

Butler C.G. (1954) The world of the honeybee, Collins, London.

Burgett M., Titayavan M. (1993) Brood thermoregulation by the giant honey bee (Apis dorsata F.), Nat. Hist. Bull. Siam Soc. 41, 93-98.

Fletcher D. (1978) The influence of vibration dances by worker honeybees on the activity of virgin queens, J. Apic. Res. 17, 3-13.

Frisch K. von (1923) Über die „Sprache“ der Bienen, eine tierpsychologische Untersuchung, Zool. Jb. (Physiol.) 40, 1-180.

Hamman E. (1957) Wer hat die Initiative bei den Ausflügen der Jungkönigin, die Königin oder die Arbeitsbienen? Insectes Soc. 4, 91-105.

Heran H. (1952) Untersuchungen über den Temperatursinn der Honigbienen (Apis mellifica) unter besonderer Berücksichtigung der Wahrnehmung strahlender Wärme, Z. Vergl. Physiol. 34, 179205.

Koeniger N., Fuchs S. (1975) Zur Kolonieverteidigung der asiatischen Honigbienen, Z. Tierpsychol. 37, 99-106.

Milum U. (1955) Honeybee communication, Am. Bee J. 95, 104.
Roepke W. (1930) Beobachtungen an Indischen Honigbienen, insbesondere an Apis dorsata F., Meded. Landbouwhogesch, Wageningen 34, 128.

Schneider S.S., Stamps J.A., Gary N.E. (1986) The vibration dance of the honey bee. I. Communication regulating foraging on two time scales, Anim. Behav. 34, 377-385.

Seeley T.D. (1985) Honeybee ecology, Princeton Univ. Press, New Jersey, p. 201.

Seeley T.D. (1992) The tremble dance of the honey bee: message and meanings, Behav. Ecol. Sociobiol. 31, 375-383.

Seeley T.D., Seeley R.H., Akratanakul P. (1982) Colony defense strategies of the honeybees in Thailand, Ecol. Monogr. 52, 43-63.

Underwood B.A. (1990a) The behavior and energetics of high-altitude survival by the Himalayan honey bee, Apis laboriosa, Ph.D. Thesis, Cornell University, Ithaca, USA, 144 p., A. A. 1212/91.

Underwood B.A. (1990b) Seasonal nesting cycle and migration patterns of the Himalayan honey bee Apis laboriosa, Natl. Geogr. Res. 6, 276-290.

Woyke J., Wilde J., Wilde M. (2001) A scientific note on Apis laboriosa winter nesting and brood rearing in the warm zone of Himalayas, Apidologie 32, 601-602.

Woyke J., Wilde J., Wilde M. (2003a) Periodic mass flights of Apis laboriosa in Nepal, Apidologie 34, 121-127.

Woyke J., Wilde J., Wilde M. (2003b) Flight activity reaction to temperature changes in Apis dorsata, Apis laboriosa and Apis mellifera, J. Apic. Sci. 47, 31-38. 